\title{
Zimbabwe tourism destination brand positioning and identity through media: A tourist's perspective
}

Farai Chigora $^{*}$, Joram Ndlovu ${ }^{2}$, Promise Zvavahera ${ }^{3}$

College of Business, Africa University, Mutare, Zimbabwe ${ }^{1 *}$

School of Social Sciences, Howard College, University of KwaZulu-Natal, Durban, South Africa ${ }^{2}$

Registry, Africa University, Mutare, Zimbabwe ${ }^{3}$

fchigora@yahoo.com ${ }^{1 *}$,ndlovuj1@ukzn.ac.za ${ }^{2}$,promisezvavahera59@gmail.com ${ }^{3}$

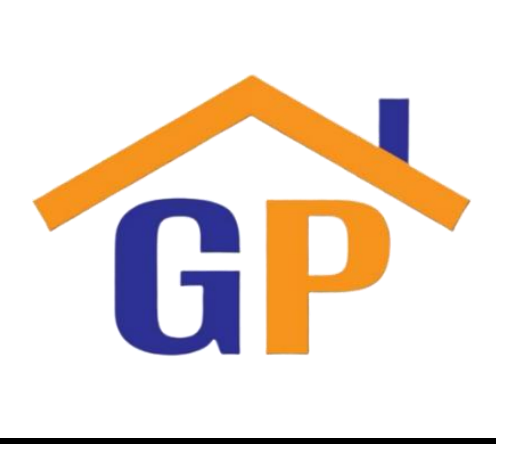

Article History

Received on 10 May 2021

Revised on 29 June 2021

Accepted on 30 June 2021

\begin{abstract}
Purpose: The study was based on understanding how media can be used to select Zimbabwe tourism destination brands against other brands by the tourists. Further, it examined the role of media in improving Zimbabwe tourism brand identity. Factors to use in positioning the Zimbabwe tourism brand were also established.
\end{abstract}

Research Methodology: A quantitative to the qualitative sequential mixed method was used to get research data. The respondents and participants to the study were tourism operators, media organizations and tourists $(n=452)$.

Results: The study's findings informed that tourism and media organizations in Zimbabwe are failing to understand the best ways to use media to attract tourists. There was a significant disagreement in the views of tourists and organizations, especially based on choosing a tourism destination brand using media. Even on improving Zimbabwe tourism destination brand identity and positioning, both parties agreed that media could help improve brand identity.

Limitations: Getting opinions and views of tourists is difficult considering the divergence in their perceptions. A mixed-methods could help in improving objectivity.

Contribution: The study, therefore, recommended an intensive tourism media audit, considering media as a strategic brand identity tool and a nationwide survey to come up with brand positioning elements specifically for Zimbabwe tourism destinations.

Keywords: Destination branding, Media publicity, Brand image, Brand identity, Brand positioning

How to cite: Chigora, F., Ndlovu, J., \& Zvavahera, P. (2021). Zimbabwe tourism destination brand positioning and identity through media: A tourist's perspective. Journal of Sustainable Tourism and Entrepreneurship, 2(3), 133-146.

\section{Introduction}

The image of a tourism destination is subject to and dependent upon both local and international media publicity. The media has developed the power to inform the state of a tourism destination at any given point in time. The power of media publicity is seen in its ability to spread both positive and negative news concerning a specific tourism destination to its existing and prospective tourists. News headlines, content and readership, or broadcasting frequency, play a significant role in building the brand image of a tourism destination. Media, therefore, also has the power to enlighten the socioeconomic state and political situation in a tourist destination. 
The performance of the Zimbabwe tourism brand has been negatively affected by various negative socio-economic and political issues over the years. There are concerns amongst various media that the country's tourism brand appeal is no longer keeping pace with time in a highly volatile and unpredictable operating environment (Mirimi, Utete, Mapingure, Mumbengegwi, \& Kabote, 2013, p. 47). The poor performance of the Zimbabwe tourism destination brand is proven by a staggering growth in tourist arrivals, especially between the years 1999 and 2015, as reflected in Table 1. Below:

Table 1. Tourists' Arrivals between Year 1999 and 2008

\begin{tabular}{|l|l|}
\hline \multicolumn{1}{|c|}{ Tourism Year } & \multicolumn{1}{c|}{ Tourists' Arrivals } \\
\hline 1999 & $2,249,615$ \\
\hline 2000 & $1,966,582$ \\
\hline 2002 & $2,041,202$ \\
\hline 2004 & $1,854,488$ \\
\hline 2005 & $1,558,501$ \\
\hline 2008 & $1,955,594$ \\
\hline 2011 & $2,423,280$ \\
\hline 2013 & $1,794,230$ \\
\hline 2014 & $1,832,570$ \\
\hline 2015 & $1,880,028$ \\
\hline & $2,056,588$ \\
\hline
\end{tabular}

Source: Zimbabwe Tourism Authority (2011, p.1; 2015, p.10)

The presentation in Table 1.1 shows significant growth in the number of tourists arrival, where numbers in respective periods are as follows: $-13 \%$ (1999 to 2000); $+4 \%$ (2000 to 2002); $-9 \%$ (2002 to 2004 ); $-15 \%$ (2004 to 2005 ); $+25 \%$ (2005 to 2008 ); $-26 \%$ (2011 to 2012 ); +3\% (2012 to 2013 ); and $+9 \%$ (2014 to 2015). The trend in tourists' arrivals reflects the poor performance of the tourism industry in Zimbabwe, which might be resolved through a tourist destination's branding and rebranding process. Branding can be a vital tool in improving the perception of potential tourists towards a tourism destination. As postulated by Mirimi et al. (2013, p. 48) looking at Zimbabwe as a destination, destination branding becomes an important component in positioning the country as a prime international tourist destination. This study proposes an inherited tourism destination brand in Zimbabwe, which may be improved through a rebranding process. Chikafu et al. (2014,p.33) have defined rebranding as creating a new name, term, symbol, design or combination thereof under the auspices of an established brand, intending to develop a differentiated (new) position in the mind of the stakeholders and competitors. Therefore, introducing media publicity in the rebranding process for Zimbabwe tourism destinations might improve its global market position and performance.

\section{Zimbabwe tourism destination publicity}

Publicity involves communicating to the public so that the published information becomes public knowledge and for public consumption (Pember \& Calvert, 2011, p. 279). Despite the adage ", any publicity is good publicity," existing studies reflect that negative publicity has adverse effects (Berger et al., 2010, p. 816). Though without reference to comprehensive literature, the effect of adverse publicity was made visible in Zimbabwe as a tourism destination. It discouraged tourism consumption, mainly by traditional tourists from the western markets. The country's perceived negative socio-economic and political affairs prompted condemnation by both traditional and prospective new tourists globally. The dilemma is that a tourism destination brand is evaluated based on the negative publicity it portrays, causing tourists to find alternative destinations, which are perceived to be both peaceful and welcoming. Therefore, negative publicity can make a tourism destination unpopular, to be potentially shunned by tourists forever, unless remedial strategies are employed. The power of negative publicity can be easily heard and transmitted through the media and word of mouth. Positive publicity meanwhile tends to have a slow positive response. Knowing the type of media to use for positive publicity of a tourism destination and its brand is the main challenge. This aspect is not put to rest in the available literature. This might be why tourism destination brands, 
amongst them Zimbabwe in particular, face a challenge in establishing a positive and type of publicity that prompts consumption.

This study has focused on the effect of media publicity on Zimbabwe destination brands to understand if media can be used to enhance the positive publicity of Zimbabwe as a tourism brand. A great percentage from a study carried out by Ndlovu \& Heath (2013) revealed that negative publicity was experienced by Zimbabwe tourism destinations in its source markets. According to Chibaya (2013, p.84), negative publicity of Zimbabwe as a tourism destination sharply increased between 2000 and 2008. This resulted in tourists' arrivals declining from 2.4 million in 2004 to 1.8 million in 2008 (UNWTO, 2011). Negative reviews and rumours can damage product evaluation, condensing purchase likelihood and sales (Huang \& Chen, 2006 cited in Berger et al., 2010, p. 816). Any published rumour has a likelihood of being consumed and discussed publicly. If the rumour is negative, then the destination will carry a bad image amongst its target markets. Bad images generated from negative publicity can derail the branding efforts of a tourism destination (Ndlovu \& Heath, 2013 , p. 947). Zimbabwe, as a tourism destination and its brand's image, therefore, suffered from negative international media publicity, resulting in reduced arrivals and low tourism revenues. Publicity then becomes an area in tourism destination media that requires intensive examination through research to build a vibrant tourism destination brand.

\section{Statement of problem}

The Zimbabwe tourism destination brand has suffered from negative perceptions amongst tourists due to the negative publicity connected to socio-economic and political events that transpired in the country. Some of the factors leading to an adverse operating environment and poor brand performance in Zimbabwe were the closure of industries associated with increased unemployment because of the Economic Structural Adjustment Programme (ESAP) in 1991, the severe drought of 1992, mass stayaways between 1996 and 1998, food riots in 1998, a land redistribution programme in 2000, repeat cholera epidemics, violent elections, and hyperinflationary macro-environment between 2000 and 2008 (Chibaya, 2013, p. 86). These unfavourable events deterred the performance of the tourism industry, especially from the year 2000 onwards. The tourism destination and its brand became increasingly unpopular in its traditional tourism markets such as Britain, Germany and America. It is evident that from the year 2000 onwards, Zimbabwe as a destination brand lost its market by developing a negative image internationally, failure to create positive awareness and perceived poor quality of the tourism products and services offered.

International media such as Cable News Network (CNN) and British Broadcasting Corporation (BBC) spread negative publicity about Zimbabwe as an unsafe tourism destination (Zibanai, 2014). On the other hand, the tourists primarily emanate from continuous negative publicity in various international media, informing news about Zimbabwe being an unsafe destination for visitors. Therefore, media has proved to have a negative impact that can deter efforts of a brand to sell the tourism destination in its target markets. From this perspective, the study specifically focused on media publicity to understand if it can positively influence the better performance of the Zimbabwe tourism destination brand. Various authors agreed that there is generally a positive relationship between media and tourism destination brand performance (Severi \& Ling, 2014; Abu-Rumman \& Alhadid, 2014; Habibi et al., 2014; Lange-Faria, 2012; Linh, 2012). However, their studies did not specifically look at the factors that can help a tourist choose a brand over others, which help create a positive identity and strengthen its market positioning. Habibi et al. (2014) explored the effect of media on brand communication, and the main focus was only on online communications with little focus on how it influences a positive tourism brand publicity. Also, Morgan et al. (2011) show only how online and offline media affects brand communications in tourism but not brand positioning and identity. This study, therefore, examined how media can influence positive publicity, positioning and identity of Zimbabwe tourism brand.

\section{Research objectives}

- To discuss the effects of media on the publicity of Zimbabwe tourism brand

- To understand how media can influence a positive image of the Zimbabwe tourism brand

- To determine the basis for tourists to choose Zimbabwe tourism destination brand 
- To establish the sources of Zimbabwe destination brand positioning

- To develop the sources of Zimbabwe destination brand identity

\section{Literature review}

\subsection{Destination branding}

According to De San Eugenio Vela (2013, p. 467) Anholt (2008a) revealed that the connection between brands and territories could be traced back to Alexander the Great (356 BC to $323 \mathrm{BC}$ ). Kim \& Lehto aver as follows:

The most comprehensive and widely used definition for destination branding has been proposed by Blain et al. (2005), who propounded that destination branding is a marketing concept relating to (1) names, terms, symbols, logos or graphics that differentiate a destination (2) conveying travel experience expectations that are uniquely associated with a destination (3) connects the visitors emotionally and reduces the costs and efforts associated with information and perceived risk (2013, p. 118).

Branding is all about creating ownership that can extend into the future, which helps differentiate and improve the identity of a tourism destination (Gartner \& Ruzzier, 2011, p. 471). The discussions reveal how destinations use branding as a tool to improve their visibility in a crowd dominated by other similar players. It also elaborates the benefits that tourists as consumers attain, mainly in the form of making tangible and visible their potential travel experience, such that tourists will not have to search for more information about a destination when they want to visit.

Destination branding is not a new area, and its relevance is increasing as the tourism industry is mainly growing (Theodhori \& Qirici, 2014). It is one of the hottest concepts to both marketers and scholars in destination marketing (Morrison, 2012). The concept has been explored since the 1990s (Yusof et al., 2014, p.1).

Historically, there were no comprehensive researches on the practice of destination branding. However, in 1995 Australia was successfully branded as a tourism destination using a Kangaroo Symbol and in 1999 realized the escalation of New Zealand using a strapline "100\% Pure New Zealand" (Morrison, 2012).

From a Zimbabwean perspective, little research has been done concerning factors that lead to the success of its tourism destination brand. In 2002, Morgan, Pritchard, and Pride made the concept of destination branding clearer (Morrison, 2012). This study explores the role of media in the performance of the Zimbabwe destination brand, as per USAID (2013), Chibaya (2013), and Zimbabwe Tourism Authority (2010). Gartner \& Ruzzier meanwhile note that:

In line with destination brand valuation, performance measurements can be done by assessing changes in the number of tourists, their expenditure levels and length of stay such that an underperforming destination brand will receive fewer tourists, with shorter lengths of stay and lower levels of spending (2011, p. 471).

Understanding the critical issues involved in destination branding is important in order to safeguard the success of any given tourism industry (Fyall \& Garrod, 2004). The steps of building a destination brand experience, as presented in Figure 1.1 below, are crucial in order to understand Zimbabwe destination brand performance and the critical issues involved. According to Morrison (2012), the first stages of developing a destination brand is to do a situation analysis, competitive analysis, residents analysis, destination image analysis whilst analyzing past marketing programmes. This means that environmental and stakeholder analysis is essential in building an effective destination brand, where there was a need to do that for Zimbabwe destination branding. 


\begin{tabular}{|l|l|l|l|l|}
\hline $\begin{array}{l}\text { Assessing the } \\
\text { destination } \\
\text { brand's current } \\
\text { situation }\end{array}$ & $\square$ & $\begin{array}{l}\text { Developing a } \\
\text { brand } \\
\text { identity and } \\
\text { brand } \\
\text { promise }\end{array}$
\end{tabular}

Figure 1. Four-steps of building destination brand experience

Source: Hudson \& Ritchie (2009) cited in Yusof et al. (2014, p. 2)

Communicating a destination's values and the power of its assets through a destination brand can help in earning a better position in a tourism market (Da Silva Oliveira, 2013, p. 2). One of the characteristics of a good destination brand is that it ought to communicate the destination's quality and experiences (Morrison, 2012). The steps presented in Figure 1.1 do not show where media fit so as to communicate and develop a better brand identity. This study investigated the effect of media in these presented stages, with the aim of determining where it might fit in Zimbabwe's destination brand communication.

\subsection{Role of media in a tourism destination}

The power of media that various agencies in a tourism destination use are that it acts as gatekeepers who can reject or select information to include in news content and spread it to the world driven by the fact that media thoroughly saturate our daily living as it moves emotions challenges the intellect and even insults intelligence within individuals and groups (Bressers \& Gordon, 2010, p. 1). The ability of the media to influence our emotions and intellect has seen tourists from various countries agreeing to the publicized news in various international media, portraying Zimbabwe as a tourism destination as hostile and dreadful to both humans and nature, which has resulted in reduced visits, with some tourists altogether rejecting Zimbabwe as a tourism destination of choice. Media helps define whom we are by picturing and shaping our interpretation of the real events surrounding us (Baran, 2011, p. 4). Therefore, destination marketers should not underestimate the possible reach of the influence of media (Ndlovu \& Heath, 2013, p. 952). From 2000 onward, we have seen media effects resulting in a damaged image for Zimbabwe as a tourism destination and its brand through negative safety reports published worldwide (Chibaya, 2013, p. 84). According to Karambakuwa et al. (2011, p. 68), Zimbabwe, as a tourism destination, faced a decrease in tourists' arrivals due to this negative media publicity. In 1999 , tourists arrivals were $2,249,615$, which decreased to $1,966,582$ in the year 2000, after which it declined further to 1,558,501 in 2005 (Zimbabwe Tourism Authority, 2010,p.1). Ndlovu \& Heath (2013, p. 952), in their study on the rebranding of Zimbabwe towards sustainable development, postulated that media could influence the perception of a destination, such that it can be used for image modification. Zimbabwe Tourism Authority spearheaded various destination marketing organizations and tried to construct a positive image by rebranding the tourism destination strategically, but little progress has been recorded to date. These discussions show that media has a negative contribution to the performance of the Zimbabwe tourism destination brand, which also resulted in a negative perception by the tourists towards the brand. However, the challenge is to establish media factors that have affected this performance and how these can be re-addressed for a more positive image, which is as important for the present as it is for the future.

\subsection{Brand positioning}

Morrison (2012) argues that a good brand should be consistent with positioning through conveying the desired image. In this case, "Zimbabwe A World of Wonders", the current brand, should be able to justify its meaning and clearly demonstrate the positioning of 'wonders' in international terms. Kotler \& Armstrong argue that:

There is a need for marketers to position their brand clearly to the minds of targeted customers looking at the three positioning levels: positioning with product attributes, positioning by associating its name with desirable benefits, and positioning on solid beliefs and values (2012, p. 244). 
The current Zimbabwe destination brand positions itself by means of product attributes. The concern is in proving whether the wonders in Zimbabwe are attractive and unique to use them in positioning the destination's brand. Morrison (2012) postulated that a good destination brand should be unique and outstanding in a competitive market.

\subsection{Brand identity}

Academic practitioners in brand management currently define the concept of brand identity as internal and an inspirational construct that originates independently from brand management (Da Silveira et al., 2013, p. 29). According to Morrison (2012), brand identity is the creativeness done in the brand development stage, such as using a new logo, color, slogan, and visual image. The issue for Zimbabwe as a destination brand is in knowing if it has a visible identity in the global tourism market, and understanding the variables can help improve its identity. Gioia et al. (2010) confirmed that internal and external influences affect brand identity development. Besides the effort of Zimbabwe destination managers to improve brand identity, external factors such as international relations and media influences might have affected the prosperity of the destination's brand identity. Several practitioners have followed the notion that brand managers need to maintain consistency in their brand identity, such that the brand becomes a constant reference to the customers (Da Silveira et al., 2013, p. 28). As presented in Figure 1.2 below, brand managers should be able to match their projected image with the desired potential tourists. According to Pike (2010, p.127): "brand identity is derived from the vision, values and personality of destination which is then conveyed in the form of a name, symbol or slogan so that at the end there is an actual image that the consumers hold."

It is not easy to know what is affecting the desire to have a positive brand identity for Zimbabwe destination, whether it is crafting the desired image, positioning elements, or the actual image held by consumers. According to Kim \& Lehto (2013, p. 120), there is little attention paid to projected images by destination marketing organizations; yet, that might be a reason for Zimbabwe destination brand identity failure. From a consumer perspective, the actual image they perceive might be attributed to negative media publicity of the country and its destination.

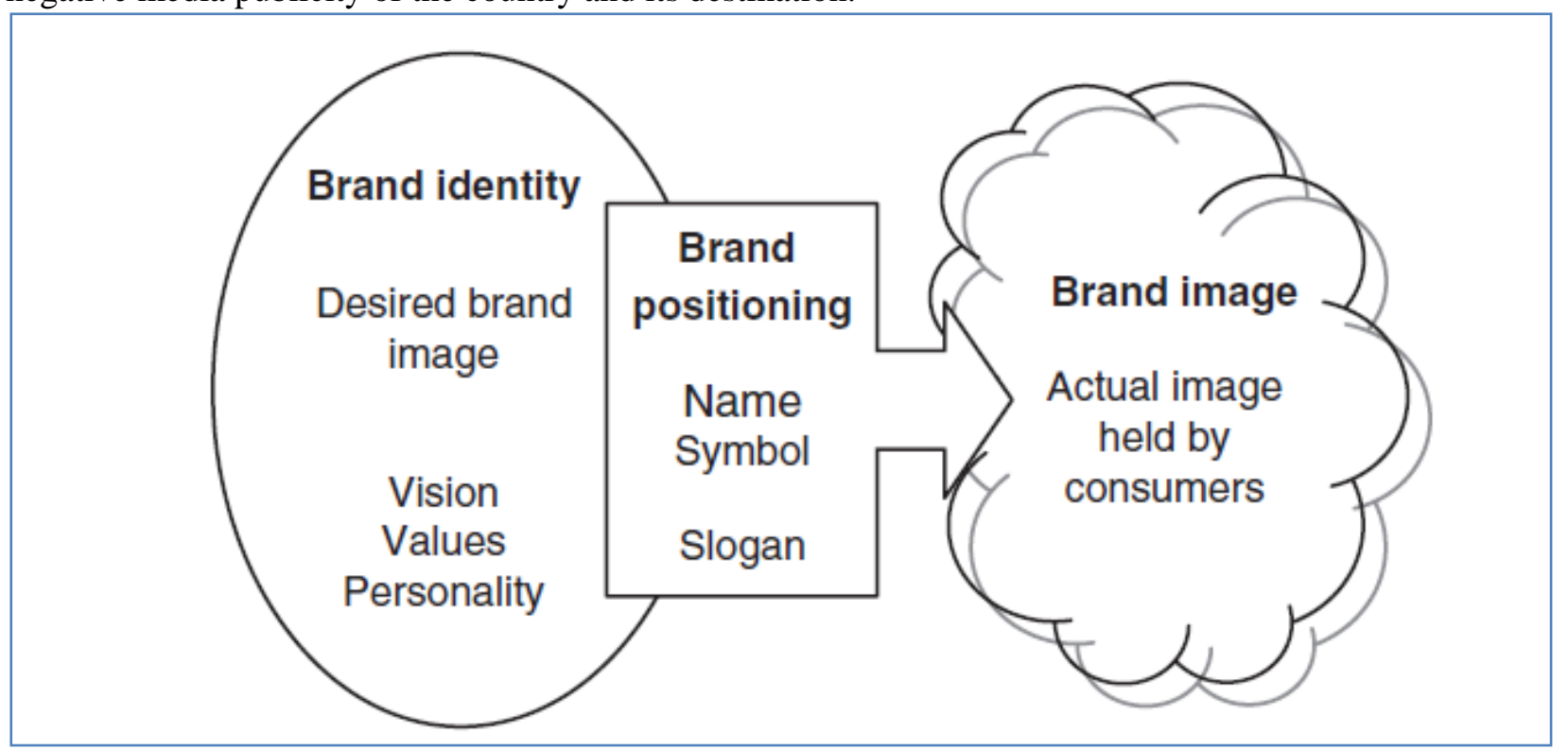

Figure 2. Brand identity and brand image

Source: Pike (2010, p. 127)

In addition, the brand positioning statements that have been used to construct the previous and current brands in Zimbabwe might not match the expectations of its target markets. Even with the assertion by Herstein (2012, p. 148) that destinations are endowed with some resources that can help to differentiate them from others in the region and at the global level, the "Zimbabwe, A World of Wonder" brand might be confusing in its meaning to the targeted audience, even it if was formulated based on Zimbabwe's natural wonders. Maybe the targeted market does not agree that there are unique 
wonders in Zimbabwe. Morrison (2012) postulated that some of the characteristics of a good destination brand should be simple, attractive and communicate destination quality. This study, therefore, investigated how media can be used in improving Zimbabwe destination brand identity.

\section{Research methodology}

Since the nature and construct of this study were based on positivism and interpretivism, it required the application of both quantitative to qualitative mixed approaches. Triangulation is a mix of both quantitative and qualitative approaches in obtaining research data (Heyvaert et al., 2011; Migiro \& Magangi, 2011). In addition, the use of mixed methods helps in providing a complete solution to a research problem than when using a qualitative or quantitative approach in isolation (Creswell, 2014, p. 32). Therefore, the study was initiated with quantitative research and was followed by qualitative research as a QUAN to QUAL sequential mixed method.

\subsection{Population and sampling procedure}

The population of the study was obtained from the three main sectors of the tourism industry that is accommodation (406), travel (204) and holiday resorts (46). Also, it was from the media industry (200) and Zimbabwe Tourism Authority (3). The study then used a stratified random sampling method to obtain respondents for the research. These were reduced into the manageable sample using Yamane (1967) sample size formula as shown below. Sample size refers to the number of elected observations in the sample of research (Singh \& Masuku, 2014). Appropriate sample size is achieved through power analysis when conducting both quantitative and qualitative investigations (Migiro \& Magangi, 2011).

\subsection{First approximation calculation}

$$
n=\frac{N}{1+N(e) 2}
$$

\subsection{Sample size calculation}

$$
n=\frac{n_{0}}{1+\frac{\left(n_{0}-1\right)}{N}}
$$

Where: $N$ = population size

$\boldsymbol{n}=$ sample size

$\boldsymbol{e}=$ sampling error or precision level (e.g. $5 \%$ for $95 \%$ confidence level), and

$\boldsymbol{n}_{0}=$ the first approximation of $n$

Yamane formula helped in calculating and determining the sample size for investigation in all tourism strata and media industries, as shown in Table 1.2 below. It also helped determine the sample size for tourists involved in the research survey, as shown in Table 1.3 below. 
Table 2. Zimbabwe tourism and media industry sample size calculation

\begin{tabular}{|c|c|c|c|}
\hline SECTOR & $\begin{array}{c}\text { POPULATION } \\
\text { *ZTA (2014) } \\
(\mathbf{N})\end{array}$ & $\begin{array}{c}\text { CALCULATED } \\
\text { SAMPLE SIZE } \\
\left(\boldsymbol{n}_{\mathbf{0}}\right)\end{array}$ & $\begin{array}{c}\text { SAMPLE SIZE } \\
(\mathbf{n})\end{array}$ \\
\hline Accommodation & 406 & 298 & 154 \\
\hline Travel & 204 & 153 & 79 \\
\hline Holiday Resorts & 46 & 35 & 23 \\
\hline $\begin{array}{c}\text { Media Organizations } \\
\text { Zimbabwe Tourism } \\
\text { Authority }\end{array}$ & 200 & 133 & 80 \\
\hline TOTAL & $3 * *$ & - & 3 \\
\hline
\end{tabular}

*Zimbabwe Tourism Authority database

** population too small to calculate with the sampling formula census sampling was used

Table 3. Tourists sample size calculation

\begin{tabular}{|c|c|c|c|c|}
\hline $\begin{array}{c}\text { *TYPE OF } \\
\text { ACCOMMODATION } \\
\text { BUSINESS }\end{array}$ & $\begin{array}{c}\text { MONTHLY } \\
\text { OCCUPANCY } \\
\text { RATE }\end{array}$ & $\begin{array}{c}\text { ** TOTAL } \\
\text { POPULATION } \\
\text { OF TOURISTS }\end{array}$ & $\begin{array}{c}\text { CALCULATED } \\
\text { SAMPLE SIZE } \\
\left(\boldsymbol{n}_{\boldsymbol{0}}\right)\end{array}$ & $\begin{array}{c}\text { SAMPLE } \\
\text { SIZE } \\
(\mathbf{n})\end{array}$ \\
\hline Hotel 1 & 82 & 82 & 68 & 37 \\
\hline Hotel 2 & 113 & 113 & 90 & 36 \\
\hline Hotel 3 & 100 & 100 & 77 & 40 \\
\hline TOTAL & $\mathbf{2 9 5}$ & $\mathbf{2 9 5}$ & $\mathbf{2 3 5}$ & $\mathbf{1 1 3}$ \\
\hline
\end{tabular}

* Determined by the number of rooms and operational size

**Monthly average occupancy rate provided by reservations office

\subsection{In-depth interviews}

The study used in-depth interviews in order to obtain qualitative and subjective data in the form of opinions and perceptions from various experts and senior managers. The participants for the interviews were chosen based on their experience, functional position, and expertise in matters to do with Zimbabwe tourism marketing and media usage. The in-depth interview respondents included those from the Ministry of Tourism and Hospitality (1), Zimbabwe Tourism Authority (1), Ministry of Media and Information Publicity (1) and Zimbabwe National Parks and Wildlife Management (1), making a total of $n=4$ participants to the in-depth interviews.

\subsection{Data collection}

Mixed methods research applies quantitative and qualitative data collection instruments, including interviews and questionnaires (Heyvaert et al., 2011, p.2). According to Harris \& Brown (2010, p.1), questionnaires and interviews are used when research is based on triangulation, such that questionnaires help in providing evidence on the patterns of a large population and interviews gathering more in-depth issues on the attitude of participants, their actions, and what they think. This study used survey questionnaires and in-depth interviews to collect research data from the respondents and participants since it was based on a mixed-methods research design.

\subsection{Data analysis}

The study was based on both quantitative and qualitative research as methods for obtaining research data. The research data were therefore analyzed using both objective and subjective methods. Software Package for Social Scientists (SPSS) version 21 was then used to analyze quantitative data, and the NVIVO software package analyzed qualitative data for the research. SPSS provided a basis 
for simple regression analysis, multiple regression analysis, the Chi-square test, the Pearson correlation test, and factor analysis.

\section{Results and discussions}

\subsection{Basis for choosing tourism destination brand}

Tourism destination brands are always competing for visitors, where the most attractive brand will get more followers in global tourism markets. Through the concept of branding, a unique proposition is created, which helps to differentiate products and services provided by one business from those of competitors (Im et al., 2012, p. 385). Those tourism brands that tourists negatively perceive are likely to fail in achieving market leadership. Therefore, it is important to understand how tourists and relevant organizations choose between competing tourism destination brands using the publicity they get from the media. The presentation in Table 1.4 below shows the responses of both organizations and tourists on their basis of choosing between competing tourism destination brands using print media.

Table 4. The basis for choosing a tourism destination brand

\begin{tabular}{|c|c|c|}
\hline $\begin{array}{c}\text { The basis for Choosing between Competing Tourism } \\
\text { destination Brands }\end{array}$ & $\begin{array}{c}\text { Tourism and } \\
\text { Media } \\
\text { Organizations } \\
\quad(\mathbf{N}=339) \\
\end{array}$ & $\begin{array}{l}\text { Tourists } \\
(\mathrm{N}=113)\end{array}$ \\
\hline $\begin{array}{l}\text { Choosing a destination brand that has positive media } \\
\text { publicity }\end{array}$ & $99.7 \%$ & $64.6 \%$ \\
\hline $\begin{array}{l}\text { Selecting the brand that has colorful designs and symbols } \\
\text { in media }\end{array}$ & $44.2 \%$ & $76.1 \%$ \\
\hline Based on historical issues presented in media & $31.6 \%$ & $92.0 \%$ \\
\hline $\begin{array}{l}\text { By selecting the one that is frequently discussed in the } \\
\text { media }\end{array}$ & $75.5 \%$ & $75.2 \%$ \\
\hline $\begin{array}{l}\text { Based on positive public comments presented in the } \\
\text { media }\end{array}$ & $81.7 \%$ & $83.2 \%$ \\
\hline Pearson Correlation & \multicolumn{2}{|c|}{-0.594 (p-value 0.291$)$} \\
\hline Spearman's rho & \multicolumn{2}{|c|}{$-0.600(p$-value 0.285$)$} \\
\hline
\end{tabular}

Destination marketers need to know the factors used in selecting a destination to travel to for a vacation (Loncaric et al., 2013, p. 373). According to Table 1.4 above, Pearson Correlation confirmed that there is a robust negative relationship of -0.594 , which is above -0.5 , with an insignificant $\mathrm{p}$-value of 0.291 , since it is above 0.05 hence, we reject the $\mathrm{H} 1$ and conclude that there is no relationship between the responses of tourists and tourism organizations on their basis of choosing between competing tourism destination brands. Spearman rho correlation was -0.600 , which has a strong negative relationship with a p-value of 0.285 , which is above 0.05 . Hence, we reject $\mathrm{H} 1$ and conclude that there is a robust negative relationship between tourists and organizations on their basis for choosing competing tourism destination brands. The differences in responses mainly emanated from the following issues: most (99.7\%) of those in tourism and media organizations choose the brand that has positive media publicity when selecting a tourism destination brand from amongst other competing brands, against $64.6 \%$ of tourists who shared the same view. This might be due to the fact that tourists are no longer choosing tourism destinations to visit based on prudence (Matos et al., 2012 , p. 1). They look for accurate positive word of mouth and personal experience in making their travel and consumption decisions. However, Zimbabwe as a tourism destination brand is eliminated from a positive publicity assessment, as informed by Ndlovu \& Heath $(2013$, p. 951), that Zimbabwe tourism destination brand has negative media publicity, which has then influenced the downfall of Zimbabwe as a tourism destination brand. In addition, there is a disagreement regarding the views of organizations and tourists when selecting the brand that has colorful designs and symbols, where tourism and media organization are $42.2 \%$ and tourists are 76.1 percent, respectively. This might be due to the fact that some media, like print media, fails to provide high-definition pictures. R3 
supported the same view by informing that the quality of printed material ought to be improved for it to be used as a vibrant publicity tool of the Zimbabwe tourism destination brand.

In summary, the responses show that tourism and media organizations fail to understand how they can effectively use media to improve tourists' consumption of Zimbabwe as a tourism destination brand. This hinders destination marketer's efforts to improve the performance of the Zimbabwe tourism brand using media in areas relevant to tourists in their appreciation of the brand.

\subsection{Sources of Zimbabwe destination brand identity}

A tourism destination brand ought to be identified as the best amongst others in the global tourism market. As presented in the literature, the main issues for constructing a brand identity include its vision, objectives, values, position, and image. The presentation in Table 1.5 below shows the responses by both organizations and tourists on the sources of Zimbabwe tourism brand identity.

Table 5. Responses by organizations and tourists on the sources of Zimbabwe tourism destination brand identity

\begin{tabular}{|c|c|c|c|}
\hline \multicolumn{2}{|c|}{ TOURISM AND MEDIA ORGANIZATIONS } & \multicolumn{2}{|c|}{ TOURISTS } \\
\hline & $\begin{array}{c}\text { Mean } \\
(\mathrm{N}=339)\end{array}$ & & $\begin{array}{c}\text { Mean } \\
(\mathrm{N}=113)\end{array}$ \\
\hline $\begin{array}{l}\text { It is based on a good image that exists in } \\
\text { the tourism destination }\end{array}$ & 1.59 & $\begin{array}{l}\text { It is due to the good } \\
\text { image of the Zimbabwe } \\
\text { tourism brand that made } \\
\text { me visit this tourism } \\
\text { destination. }\end{array}$ & 3.02 \\
\hline $\begin{array}{l}\text { It comes from a clear vision of the tourism } \\
\text { destination's brand. }\end{array}$ & 4.20 & $\begin{array}{l}\text { The vision of the } \\
\text { Zimbabwe tourism } \\
\text { brand is clear and I } \\
\text { understand its meaning. }\end{array}$ & 4.00 \\
\hline $\begin{array}{l}\text { It is based on meaningful values of the } \\
\text { tourism destination's brand. }\end{array}$ & 3.88 & $\begin{array}{l}\text { Zimbabwe tourism } \\
\text { brand is based on clear } \\
\text { values of the tourism } \\
\text { destination. }\end{array}$ & 4.18 \\
\hline $\begin{array}{l}\text { It matches with a good personality that is } \\
\text { expected by tourists. }\end{array}$ & 3.71 & $\begin{array}{l}\text { I know the personality of } \\
\text { the Zimbabwe tourism } \\
\text { brand and it matches } \\
\text { with my own } \\
\text { personality. }\end{array}$ & 4.28 \\
\hline $\begin{array}{l}\text { It can be improved through the use of } \\
\text { media promotion. }\end{array}$ & 1.86 & $\begin{array}{l}\text { Media has helped me to } \\
\text { identify Zimbabwe } \\
\text { tourism destination and } \\
\text { its brand in the global } \\
\text { tourism market. }\end{array}$ & 1.67 \\
\hline Paired Sample & atistics & 271 (p-value :0.273) & \\
\hline
\end{tabular}

Table 1.5 above shows that the paired sample t-test statistic was found to be -1.271 , with a p-value of 0.273 , which is greater than 0.05 , and hence we accept $\mathrm{HO}$ and conclude that there is no significant difference between the mean responses of tourists and organizations. As informed by R1, media has the advantage of wide coverage, which might help in improving the global identity of the tourism 
destination brand. This means that there is great potential for improving the identity of Zimbabwe as a tourism destination brand through media publicity as reflected by an agreement by organizations that brand can be improved through the use of media promotions (1.86), whilst tourists share the same, by agreeing that media has helped them to identify Zimbabwe tourism destination and its brand on the global tourism market (1.67).

\subsection{Sources of Zimbabwe destination brand positioning}

Destination marketers ought to strive to create an effective positioning strategy for the destination to differentiate it from competitors in the customers' minds (Matos et al., 2012, p. 110). Brand positioning can be done as symbolic positioning, functional positioning, and positioning through experience (Janiszewska, 2012, p. 13). Table 1.6 below presents survey findings on sources of Zimbabwe tourism brand market positioning.

Table 6. Responses by organizations and tourists on the sources of Zimbabwe tourism destination brand position

\begin{tabular}{|l|l|l|l|}
\hline \multicolumn{1}{|c|}{ TOURISM AND MEDIA ORGANIZATION } & \multicolumn{2}{|c|}{ TOURISTS } & $\begin{array}{c}\text { Mean } \\
\text { (N=113) }\end{array}$ \\
\hline $\begin{array}{l}\text { The tourism destination's brand } \\
\text { name has a clear meaning. }\end{array}$ & 4.39 & $\begin{array}{l}\text { I know and understand the } \\
\text { meaning of the Zimbabwe } \\
\text { tourism brand name. }\end{array}$ & 4.07 \\
\hline $\begin{array}{l}\text { Symbols that have been used to } \\
\text { position the tourism destination } \\
\text { brand connects with the expectations } \\
\text { of the tourists. }\end{array}$ & 3.60 & $\begin{array}{l}\text { I am familiar with the } \\
\text { symbols that were used to } \\
\text { represent the Zimbabwe } \\
\text { tourism brand. }\end{array}$ & 3.97 \\
\hline $\begin{array}{l}\text { There are slogans associated with the } \\
\text { positioning of Zimbabwe tourism } \\
\text { brand. }\end{array}$ & 1.83 & $\begin{array}{l}\text { Slogans used in Zimbabwe } \\
\text { tourism destination brand } \\
\text { promotion increase the } \\
\text { desire to visit the tourism } \\
\text { destination. }\end{array}$ & 4.36 \\
\hline
\end{tabular}

Results in Table 1.6 above show a high cause of concern with regards to Zimbabwe tourism brand position. This is because the majority of the responses are in a negative range, with means above 3 . Both the organizations and tourists disagreed that the Zimbabwe tourism brand name has a clear meaning (4.39 and 4.07, respectively). The symbols used to construct the tourism brand connect with the tourists' expectations (3.6 and 3.97, respectively). There was a gap in responses between the two parties with regards to slogans used in promoting Zimbabwe as a tourism destination, as the organization highly (1.83) agreed that they use slogans to promote Zimbabwe as a tourism brand, yet a high disagreement (4.36) by tourists that slogans used to promote the tourism brand attracts them to visit Zimbabwe as a tourism destination. The use of names, symbols and logos helps in uplifting a brand (Barišić, 2014, p. 27). This means that tourists do not know or even use these slogans to make their consumption decision for the Zimbabwe tourism destination brand, even with slogans by tourism and media organizations. Brand positioning ought to be externally driven (Janiszewska, 2012, p. 11), meaning that it should come from tourists. $R 4$ agreed, saying that the improved visibility can improve the market position of Zimbabwe as a tourism brand from pictures presented in media. The results clearly show that Zimbabwe as a tourism destination brand is currently in a dire state, which needs to be addressed through correcting the gaps in knowledge and publicity between organizations and tourists. 


\section{Conclusion}

Essentially, the study informed that the tourism and media organizations in Zimbabwe are failing to understand the best ways to use media so as to attract tourists. There is a great disagreement in the views of tourists and organizations especially based on choosing a tourism destination brand using media. Even on the factors for improving identity and positioning of the destination brand the study revealed a high divergence of view from both parties. The tourists showed that they get more information about a destination brand from direct word of mouth rather than media use. Tourists are attracted by the colorful presentations of a brand in the media and tourism and media organizations seem to be doing little effort from this perspective. Operators in the tourism and media organizations informed that the Zimbabwe destination brand has a clear meaning in its target markets yet the tourists disagreed with this view. Also, with regards to symbols that have been used to construct the Zimbabwe tourism brand, tourists informed that they are not connected to these symbols. Lastly, tourists informed that the slogans used by tourism and media organizations to promote Zimbabwe tourism destination brands are not attractive to them. However, on the positive, both the organizations and tourists have agreed that positive media publicity can help improve Zimbabwe tourism destination brand identity.

\section{Recommendations}

- There is a need to conduct an intensive tourism media audit in Zimbabwe to develop the best tourism marketing media policy that considers the views of the operators and tourists. This helps improve consistency in media promotions and even invest in the correct areas that attract tourists.

- The destination marketing organizations in Zimbabwe should invest more effort to understand the main factors tourists consider to help them identify Zimbabwe tourism destination brands from other brands on the market. Media should also be considered as it has been found to have a role in improving identity and its fit should be established for Zimbabwe tourism destination vibrancy.

- There is a need to re-align the positioning elements that are currently used for the Zimbabwe tourism destination brand. It is also important to carry out a nationwide survey to come up with symbols, slogans, and any other factors that improve Zimbabwe tourism destination brand positioning.

\section{References}

Abu-Rumman, A. H., \& Alhadid, A. Y. (2014). The impact of social media marketing on brand equity: An empirical study on mobile service providers in jordan. Review of Integrative Business and Economics Research, 3(1), 315-326.

Anholt, S. (2008). From nation branding competitive identity-The role of brand management as a component for national policy. In K. Dinnie (Ed.), Nation Branding: concepts, issues, practice, 22-23. Oxford UK: Butterworth- Heinemann.

Baran, S. J. (2011). Media Literacy and culture. New York: McGrawHill.

Barišić, P. (2014). National brand and its elements: Value, power and competitiveness. International Journal of Business Tourism and Applied Sciences, 2(2), 1-6.

Berger, Jonah, Alan Sorensen, and Scott Rasmussen (2010), Positive effects of negative publicity: When negative reviews increase sales, Marketing Science, 29, 5, 815-27.

Blain, C., S. E. Levy, and B. Ritchie. (2005). Destination branding: Insights and practices from destination management organizations. Journal of Travel Research, 43(4), 328-83.

Bressers, B. B., \& Gordon, J. (2010). Increasing publicity and thematic news coverage: The Impact of Localizing News Releases in a State-Wide Experimental Field Study. Public Relations Journal , 4 (4), 1-10.

Chibaya, T. (2013). From 'Zimbabwe Africa's paradise to zimbabwe a world of wonders': benefits and challenges of rebranding zimbabwe as a tourist destination. Developing Country Studies, 13(5), 84-91.

Chikafu, J., Mirimi, K., \& Hurombo, B. (2014). Destination rebranding paradigm in Zimbabwe: A stake holder approach. International Journal of Advanced Research in Management and Social Sciences, 3(1), 30-41.

Creswell, J. W. (2014). Research design: Qualitative, quantitative and mixed methods approaches. Los Angeles: SAGE. 
Da Silveira, C., Lages, C., \& Simões, C. (2013). Reconceptualizing brand identity in a dynamic environment. Journal of Business Research, 66, 28-36.

De San Eugenio Vela, J. (2013). Place branding: a conceptual and theoretical framework. Boletín de la Asociación de Geógrafos Españoles, 62, 467-471.

Fyall, A., \& Garrod, B. (2004). Tourism marketing: A collaborative approach. Clevedon, UK: Channel View Publications.

Gartner, W. C., \& Ruzzier, M. K. (2011). Tourism destination brand equity dimensions: renewal versus repeat market. Journal of Travel Research , 50(5), 471-481.

Gioia D. A., Price K. N., Hamilton, A. L. Thomas, J. B. (2010). Forging an identity: an insideroutsider study of processes involved in the formation of organizational identity. Adm Sci $Q$, $55(1), 1-46$.

Habibi, M. R., Laroche, M., \& Richard, M.-O. (2014). The roles of brand community and community engagement in building brand trust on social media. Computers in Human Behavior (37), 152161.

Harris, L. R., \& Brown, G. T. (2010). Mixing interview and questionnaire methods:Practical problems in aligning data. Practical Assessment, Research, 15(1), 1-19.

Herstein, R. (2012). Thin line between country, city, and region branding. Journal of Vacation Marketing, 18(2), 147-154.

Heyvaert, M., Maes, B., \& Onghena, P. (2011). Applying mixed methods research at the synthesis level: An overview. Research in the Schools, 18(1), 12-24.

Im, H. H., Kim, S. S., Elliot, S., \& Han, H. (2012). Conceptualizing destination brand equity dimensions from a consumer-based brand equity perspective. Journal of Travel \& Tourism Marketing, 29, 385-403.

Janiszewska, K. (2012). The strategic importance of brand positioning in the place brand concept:elements, structure and application capabilities. Journal of International Studies, 5(1), 9-19.

Karambakuwa R.T., Shonhiwa, T., Murombo, L., Mauchi, Gopo, N.F., Denhere ,W., Tafirei, F., Chingarande, A., and Mudavanhu, V. (2011). The impact of Zimbabwe tourism authority initiatives on tourist arrivals in Zimbawe (2008-2009). Education Journal of Sustainable Development in Africa, 13(6), 1520-5509.

Kim, S., \& Lehto, X. Y. (2013). Projected and perceived destination brand personalities: the case of South Korea. Journal of Travel Research, 52 (1), 117-130.

Kotler, P., \& Armstrong, G. (2011). Principles of Marketing 14th Edition. New York: Pearson Prentice-Hall.

Lange-Faria, W. (2012). Understanding the role of social media in destination marketing. Tourismos: An international multi-disciplinary Journal of Tourism, 7 (1), 193-211.

Linh, D. T. (2012). Practice of internet marketing in destination branding. Management Research, 2(4), 296-309.

Loncaric, D., Bašan, L., \& Markovic, M. G. (2013). Importance of DMO websites in tourism. marketing in a dynamic envinronment - academic and practical insights. 23rd CROMAR Congress, Congress Proceedings, 373-384. Opatija, Croatia.

Matos, N., Mendes, J., \& Valle, P. (2012). A model development of relationships between tourism experiences and destination image. 2nd Advances in Hospitality and Tourism Marketing and Management Conference, 1-8. Faro, Portugal.

Migiro, S. O., \& Magangi, B. A. (2011). Mixed methods: A review of literature and the future of the new research paradigm. African Journal of Business Management, 5(10), 3757-3764.

Mirimi, K., Utete, B., Mapingure, C., Mumbengegwi, P., \& Kabote, F. (2013). Appropriateness of branding as a tourism resuscitation tool for zimbabwe. American Journal of Tourism Management , 2(2), 47-54.

Morgan, N. Pritchard, A. and Pride, R. (2011). Destination brands: Managing place reputation. Published by Elsevier Ltd. All Rights Reserved. DOI: 10.1016/B978-0-08-096930-5.10001-1 uk

Morrison, A. M. (2012). Marketing and managing tourism destinations. London: Routledge.

Ndlovu, J., \& Heath, E. (2013). Rebranding of Zimbabwe to enhance sustainable tourism development: Panacea or villain. Academic Journals, 1(12), 947-955. 
Pember, D. R., \& Calvert, C. (2011). Mass media law. New York: McGraw-Hill Companies.

Pike, S. (2010). Destination branding case study: Tracking brand equity for an emerging destination between 2003 and 2007. Journal of Hospitality \& Tourism Research, 34(1), 124-139.

Severi, E., \& Ling, K. C. (2014). The impacts of electronic word of mouth on brand equity in the context of social media. International Journal of Business and Management, 9(8), 85-96.

Singh, A. S., \& Masuku, M. B. (2012). An insight in statistical techniques and design in agricultural and applied research. World Journal of Agricultural Sciences, 8(6), 568-584.

Theodhori, O., \& Qirici, E. (2014). The impact of destination branding to tourists behavior albania in focus. Scientific Papers International Conference, 1-7.

United Nation World Tourism Organisation. (2011). Tourism highlights. Retrieved from ww.unwto.org/pub//(May 11, 2016)

USAID. (2013). Positioning the zimbabwe tourism sector for growth: issues and challenges. USAID Strategic Economic Research and Analysis: Zimbabwe SERA Program, 1-26.

Yamane, Taro. (1967). Statistics, an introductory analysis, 2nd Ed. New York: Harper and Row.

Yusof, M. F., Ismail, H. N., \& Omar, R. N. (2014). A critical analysis on evolution of branding destination in langkawi island. SHS Web of Conferences 12, 01002.

Zibanai, Z. (2014). Marketing destination zimbabwe during and post the 2000-2008 political and economic crises. Journal of Tourism Management Research, 1(1), 14-26.

Zimbabwe tourism Authority. (2010). Tourism Trends Annual Report. Harare, Zimbabwe.

Zimbabwe tourism Authority. (2011). Tourism Trends Annual Report. Harare, Zimbabwe. 